\title{
Nas Dobras de Práticas de Licenciatura em Matemática: Um Exercício Narrativo Antropofágico de Rigor ${ }^{1}$
}

\author{
In the Folds of the Math Teacher Education Practice's: a Rigor's \\ Anthropophagic Narrative Exercise \\ Danilo Olímpio Gomes ${ }^{\mathrm{a}}$
}

a Departamento de Educação Matemática, Universidade Estadual Paulista Júlio de Mesquita Filho, Rio Claro, Brasil/ Instituto Federal de Educação, Ciência e Tecnologia de Alagoas, Piranhas, Brasil - danilo.o.gomes@ gmail.com

Palavras-chave: Narrativa ficcional. Prática docente. Práticas de poder. Paradoxo do barbeiro. Rigor.

\section{Keywords:}

Fictional narrative.

Teaching practice.

Power practices.

Barber's paradox. Rigor.
Resumo: O objetivo deste artigo é proporcionar ao leitor um encontro com uma situação ficcional composta em forma de intermezzo, ou seja, de intervalo improvisado entre dois atos de uma peça musical. Por meio de um corte-devir num desdobramento do chamado paradoxo de Russell, a intenção é levar o leitor a desmontar-se junto às entrelinhas dessa peça musical torta e dissonante, de forma a compor junto a ela suas próprias interpretações acerca da formação do professor de matemática, bem como de todas as ramificações que desse tema podem desabrochar. Um encontro com dedos, tentando capturar notas na velocidade infinita de uma obra sempre inacabada. Um mergulho em linhas emaranhadas, notas vibráteis, agenciadoras de desejos, sempre à espreita de linhas de fuga.

Abstract: The objective of this paper is to provide the reader a meeting with a fictional situation composed in the shape of intermezzo, that is, improvised interval between two musical pieces. Through a cut-off in an unfolding of the so-called Russell's paradox, the intention is to get the reader to dismantle himself between the lines of this crooked and dissonant musical piece, in order to compose with it his/her own interpretations about the mathematics teacher training math, as well as all the ramifications that this theme can unfold. A meeting with fingers, trying to capture notes at the infinite speed of an ever-unfinished work. A dip in tangled lines, vibrating notes, wish-seekers, always lurking for escape lines.

${ }^{1} \mathrm{O}$ autor agradece aos pareceristas pelos comentários e sugestões. 


\section{Introdução}

Este texto propõe uma produção no entre, um intermezzo. Numa peça musical seria o breve intervalo entre dois atos, uma pequena composição geralmente executada por meio de improviso. Aqui, um infinitesimal improvisado num entre-vários, partícula vibrátil composta à medida que o autor deixa-se levar por afetações decorrentes de (re)encontros com o que já foi, na medida em que vai se tornando. Na medida em que se permite dissolver em notas e passa a integrar as fusas e semifusas vibratórias nos pentagramas conduzidos pelas mãos da compositora-regente: a própria obra. Como salienta Lispector (1987), só tinha a ordem de respirar. De resto, deixei-me acontecer.

Um exercício narrativo, composto por resquícios de práticas. Práticas de sala de aula e o encontro com um aluno de sexto ano chamado Gabriel. Práticas de pesquisa de mestrado (GOMES, 2013; GOMES et al., 2015) e o encontro com Beth, então estudante de um curso de licenciatura em matemática. Práticas de voo e o encontro com Nietzsche $(1976$; 1978) e Foucault (1987; 1992a; 1992b; 2000) e Deleuze e Guattari (2010; 2011) e... Práticas de rigor e o encontro com um barbeiro e um paradoxo (GONDIM; GOMES, 2016). Práticas de si e o encontro com o instante-já inalcançável da escrita. Práticas de doutorado, de grupo de estudo, orientação e pesquisa e o olhar frente ao horizonte que sempre se expande. Práticas de... e...

Tentar explicar o que segue seria frear bruscamente o movimento vibratório das cordas que ressoam nessa pequena peça musical de intervalo. Sendo assim, convido quem lê e espera pelo próximo ato, a sentar-se confortavelmente em sua poltrona e a integrar essa composição feita de improviso, sentindo cada linha e entrelinha vibrar.

Eis um pequeno fato $^{2}$ :

Você vai ter os pelos aparados.

Porque é tão difícil para algumas pessoas acreditarem nesse fato irrevogável? Alguns já nascem com muito disso pelo corpo, outros adquirem ao longo da vida: herança da circunstância de serem mamíferos, humanos e organizados segundo uma forma, uma métrica e uma estética naturalizadas. Até mesmo os alopecianos, alguma vez na vida, chegam a ter aparados de sua cútis seus apêndices filiformes e coniformes - mesmo que seja em seus mais tenros sonhos. 
Faço isso com vontade, com determinação. É para isso que existo. Só não me peçam para ser ameno, para aparar somente um pouco e deixar sobressalente o emaranhado de pelos: não há como ter passado pelas minhas mãos e restarem rebarbas.

Aos que pensam que fazer o que faço é algo para qualquer menino de nariz escorrendo, saibam que a destreza só pode vir através de muitas práticas. Não há como aprender através de livros, mesmo que tenham muitas figuras. Mesmo participando de cursos preparatórios oferecidos pelos grão-mestres, somente aquele que empunhar a navalha saberá do que ela é capaz, saberá o que é ter em suas mãos aquele objeto metálico que carrega em seu fio toda a sua potência. Somente estando de frente para aquela penugem enfincada num pedaço de pele suína - pois é assim que operamos as práticas iniciais - com as mãos trêmulas e o suor escorrendo pela testa, somente naquele momento é possível saber o que pode um aparador de pelos.

Mesmo que o couro de treinamento seja muito mais áspero que a doce pele humana, o ato de deslizar o fio suavemente, sentindo cada ranhura, cada poro estalando delicadamente e deixando repousar no aço o pelo inerte, transforma em navalha a mão daquele que apara. Não há mais uma simples extensão corporal produzida pela gélida liga metálica: o sangue passa a correr pelo interior do fio.

Lembro-me como se fosse ontem de meu primeiro cliente: tinha pelos na nuca. Estranhamente, os tivera deixado ali até o momento em que decidira adentrar minha recéminaugurada barbearia e, mais estranho ainda, o fato de ter determinado, de súbito, deixar as costas de seu pescoço totalmente lisas. Mas não perguntei o motivo. Nunca pergunto. Apenas faço o que tenho que fazer. Conversar não me agrada. Mas escuto, já que não há como tapar os ouvidos tendo as mãos ocupadas.

O pobre homem disse que afagava os pelos todas as noites antes do sono, e somente com aquilo era possível dormir tranquilamente - dormia levemente de lado, com a mão direita abraçando o corpo pela frente e repousando sobre a penugem cervical. Lembro-me que fechou os olhos por vinte e sete segundos. Ao abri-los, fixou o olhar em seu reflexo e disse que após a mudança na chefia do departamento, os pelos começaram a incomodar, de forma que foi levado a escolher entre continuar produzindo o que sempre produziu durante a vida toda ou aparar os pelos da nuca. Evidentemente, escolheu a segunda opção.

Ao final do dia, varrendo o chão recoberto por pelos de todas as cores, texturas e tamanhos - adorava ficar pisando-os e sentindo-os friccionarem uns nos outros - surpreendime pensando naquela criatura. Como poderia ele aparar a própria nuca, sem lesionar-se ou ter que fazer minuciosos malabarismos frente a espelhos milimetricamente antepostos? Como 
utilizaria a navalha de maneira correta, empunhando-a com aquelas mãos que, de tão ingênuas, deixaram-se seduzir pela maciez de pelos em detrimento ao osso e ao metal?

E foi naquele momento, após o primeiro dia de efetivo exercício de minha nobre profissão que decidi: dedicar-me-ia somente a aparar os pelos daqueles incapazes de fazê-lo de forma precisa e adequada. Nos primeiros meses houve escassez de clientela, afinal, o fato de ter que assumir que não se conseguia aparar os próprios pelos, a própria barba, era algo impensável naquele meio em que aparadores de pelo eram tão inexperientes ou mesmo inexistentes. Sim, sou muito experiente - e quem duvidar disto, que pegue sua navalha e tente deixar mais liso que minhas hábeis mãos!

Ao verem os resultados de tamanho primor, aos poucos o número de clientes foi aumentando e, em algum tempo - não me pergunte quanto -, todo o horário do expediente era dedicado ao corte. Praticamente toda a cidade frequentava aquilo que se tornou muito mais que o meu ambiente de trabalho: era meu próprio ser transcendendo os limites do corpo e repousando em cada instrumento, em cada ranhura do couro da cadeira, em cada fóton emanado do barber pole. Eu era a barbearia. E aparar os pelos daqueles que não podiam fazêlo, e somente daqueles, tornou-se a atividade início-meio-fim de minha vida. Passei a fazer isso, e somente isso.

Chega de lembranças. Não quero ficar dando explicações dos modos pelos quais cheguei até aqui - mesmo porque as cortinas do tempo sobrepuseram-se às muitas vezes em que me dispus a aparar. Em alguns casos, chegaram a me perguntar: quando tem início sua carreira? Ora, humanos nascem com pelos! Perguntas dessa estirpe são totalmente imbecis, não é mesmo? É por isso que prefiro o silêncio. Além disso, não possuo simpatia e nem pretendo possuir. Apenas disse o que foi dito para aquecer os dedos e acostumá-los a movimentos outros que não sejam os de empunhadura da navalha. A mim cabe desempenhar o meu dever, e somente isso. E se aqui me disponho a falar, é porque quero. E somente isso.

Já escutei muito em minha vida. Depois de aparar pelos, é o que de melhor faço. Fico ali, de pé todos os dias, aparando e escutando. Ao longo de minha carreira, em minha cadeira de couro sentaram-se muitas pessoas, muitas. Não sei quantas, mas muitas. Na verdade sei, mas não preciso falar o número. Para quê? Basta que saiba que acomodados em minha frente, sob o olhar quente do fio de minha navalha, estiveram todos os tipos de pessoas. Humanos. Mamíferos. Pelos. Tanta variedade que meu catálogo precisou de um cômodo todo para se acomodar. Variedades em demasia que, à medida que foram catalogadas, demonstraram algo em comum - e não tinha relação com a textura ou com a cor dos pelos. As mãos. Gosto de mãos. Preciso delas para viver e observo a dos outros. Fetiche. E havia lá o calo, entre as 
falanges médias e as distais do dedo médio da destra. O detalhe que me fazia procurar em outros o mesmo detalhe. Operadores de tinteiros.

Gostava daquilo, muitos tinham os calos levemente azulados, denunciando a falta de um banho bem tomado - fato corroborado pela quantidade de caspa em seus couros cabeludos. Já outros, tinham pouco ou quase nenhum, flagrante de que haviam acabado de deixar a posição de meros aspirantes. Mas o fato é que todos, sem distinção, tinham a marca característica daqueles que enlaçam e modelam pensamentos. Meu trabalho os agradava. Gostavam do meu trabalho. E gosto, não se discute.

Todas as terças, às dezesseis horas. Esse era o horário de Mr. Collins. Era o único dia em que se permitia estar livre do trabalho, esticar as pernas e aparar os pelos. O preço pela liberdade semanal era carregar consigo a filha, Beth, cuja tutela pertencia a ele naquele dia da semana. Adolescente, prestes a terminar o curso de aspirantes a tinteiros.

Acompanho sua vida desde que começou a manejar os simuladores. Menina ávida por conhecimento, cuja curiosidade chegava a ser irritante na maioria dos casos. Ficava lá, olhando minhas hábeis mãos darem conta da face já enrugada do pai. Na maioria das vezes, nem percebia sua presença, visto que minha atenção, quando não estava sobre os pelos sobressalentes, focava o calo - e que calo, diga-se de passagem. Tinha-o em forma dupla, caso raro - tanto que, ao lado de seu nome, no quarto-catálogo, havia um desenho de duas saliências, lembrando duas corcovas de camelo e, logo abaixo, os dizeres "calo duplo". Admirável.

Beth sempre levava um livro, sempre estava absorvendo as palavras impressas de forma ávida, sedenta, impulsiva, quase maníaca. Ela queria comer aquelas páginas tanto quanto eu queria morder os calos de seu pai, arrancá-los com meus próprios dentes e fixá-los sobre as corcovas desenhadas. Todas as terças a mesma coisa. Ao final, após exatos quarenta minutos - fazia questão de que fosse exatamente este tempo para todos os clientes - $\mathrm{Mr}$. Collins falava:

— Beth, fale ao barbeiro sobre as descobertas da semana.

E naquele cenário, com Mr. Collins arrumando o colarinho de sua camisa de seda impecavelmente passada e engomada, ainda sentada, Beth desatava a falar de símbolos, relações, linhas, curvas, tracejados cada vez mais complexos envolvendo canetadas cada vez mais densas. Eu só escutava, como sempre, arrumando minhas coisas no balcão - mas sempre fazia questão de olhar para suas mãos. O calo demorava a aparecer. Estava lá, incutido, mas como uma sombra ainda, uma miragem. Não via a hora de poder deslizar a lâmina por sobre sua pele, mas o calo era necessário. O rito de iniciação era necessário e, por mais que já tivesse utilizado a tesoura algumas vezes para aparar seus cabelos, nada se igualaria ao dia em 
que minha lâmina seria conduzida ao encontro de sua cútis. Quando ela ia embora segurando a mão do pai, olhava os dois afastando-se e imaginava: Ela não percebe que tudo está coberto de pelos?

Encontrar Beth em minha barbearia sempre trazia pensamentos estranhos a minha mente. Um dos mais macabros residia no fato de pensar no que ocorreria caso os filhos de meus clientes não fossem conduzidos a adquirirem seus próprios calos. Como poderia eu seguir minha profissão? Mas cada um deles, cavalheiros de prestígio, que galgaram seu espaço na nobre terra em que habitam, sempre conseguia encontrar uma solução: mesmo que não fossem filhos legítimos a herdar suas técnicas, filhos postiços o fariam, os quais eram levados à condição de operador de tinteiro e, consequentemente, a sentarem em minha cadeira impecavelmente lustrada e à espera de novos calos. Sempre foi assim - e não fiquem pensando desde quando esse sempre existe: já disse que perguntas imbecis não devem sequer ser cogitadas!

Terça feira, dezesseis horas. Dezesseis horas e um minuto. Dezesseis horas e seis minutos. Não era possível. Depois de uma vida toda, Collins havia mudado de cidade? Após uma vida toda de total entrega poderiam aqueles calos ter deixado de habitar minha barbeariaser? Ele nunca havia se atrasado antes! Dezesseis e treze. Olho para a porta e a vejo. Não era possível existir aquilo que estava vendo: Beth, desacompanhada de seu pai, com um vestido preto, a cintura enrolada por uma faixa azul. Estupenda. No cabelo, um coque impecavelmente moldado por alguém habilidoso - não tão hábil quanto eu, é claro. Meu olhar procurou suas mãos, eu sabia o que aquela faixa azul significava. $\mathrm{O}$ ar de meus pulmões quase percorreram minhas cordas vocais naquele momento: Mostre logo suas mãos menina! Contive-me.

Delicadamente, com as mãos por trás das costas, com passos pequenos e suaves, foi adentrando, perambulando seu olhar através de todos os meus instrumentos, através de seu reflexo no espelho, voltando-o para seus pés que, seguindo um ante outro, levaram seu corpo em direção de minha cadeira. Fiquei ali, recostado em meu balcão, fitando-a aproximar. Será que se sentaria? Será que, por vontade própria, seria levada a reclinar-se no encosto de couro de minha cadeira? Parou bem atrás do assento, ainda com as mãos para trás e, olhando para o espelho, de forma fixa, começou a falar:

- Foram anos árduos, em que fui muito além de mim mesma para que este dia chegasse. Fui levada a ter companhias outras que não foram as de meus irmãos, que queriam somente transferir a nobre arte tinteira - sim, o que mais queria era passar adiante, e não somente levar comigo aquilo tudo que interiorizei. Aqueles postiços que lá estavam para absorver e reter incomodavam-se com minha presença e, nos cômodos de nossa casa, onde compartilhávamos o mesmo ar, respirar tornou-se cada vez mais difícil. Todas as atenções se 
voltavam para eles, tudo era voltado para que o ego tinteiro daqueles seres fosse elevado a limites impensáveis. Papai nunca me ensinou a maneira correta de se empregar tudo aquilo junto aos aspirantes, nunca me foi elucidado como aquilo tudo seria aproveitado no momento em que estivesse lá, com os pequeninos - se é que um dia eu estaria de fato, já que isso não era a vontade de papai.

Eu permanecia em silêncio, compenetrado, ouvindo cada palavra, cada puxada de ar entre uma frase e outra:

- Desde que me dei conta de quem era filha, desde que as aulas preparatórias tiveram início, não tinha certeza de que era aquilo mesmo que queria. Tentei fazer outras coisas, tentei refletir acerca de outros meios de se enlaçar pensamentos, mas ser operadora de tinteiro estava no sangue - pelo menos era o que papai pensava. Pelo menos é o que me fez pensar. Ser filha do tão famoso Mr. Collins me colocava no rol de pessoas que deveriam ter prosperidade, que deveriam ter seus tinteiros empunhados e traçar as mais suaves linhas de captura. Em meio a tanta cobrança, não tive escolha e, já no início, estava subjetivada a seguir os passos que papai queria que seguisse. No entanto, no contato com alguns de meus pequenos irmãos, vi que havia outra possibilidade: a de compartilhar tudo aquilo.

Silêncio.

— Nunca gostei de tamanha teoria. Nunca. Papai empurrava-a garganta abaixo, a seco, e eu tinha que engolir sem derramar uma lágrima sequer. Aquilo se seguiu até que um de meus irmãos parou ao meu lado, vendo-me mastigar aquilo tudo com muita dificuldade, e disse de supetão: Você daria uma ótima transferidora. Não entendi de imediato, mas, ao ajudar os irmãos menores, compreendi o que ele tinha me dito: precisava seguir outros caminhos. E, a partir daquele dia, segui duas trilhas paralelas: uma para satisfazer papai e outra para satisfazer meu verdadeiro desejo, meu verdadeiro propósito de vida - mesmo que secreto.

As suas palavras não faziam sentido para ouvidos tão treinados quanto os meus. O que significava tudo aquilo que Beth estava dizendo? Onde ela queria chegar com aquele discurso? Quando é que iria mostrar-me seu calo recém-adquirido para eu poder matar a curiosidade de anos e verificar se seriam como corcovas de camelo, assim como o de seu pai? Levei o olhar para além de seu corpo, tentando enxergar através. Não queria me movimentar do lugar onde estava, pois corria o risco de assustá-la. Os seus olhos não estavam mais enxergando seu reflexo, estavam olhando para além da película metálica atrás da areia aquecida. E, após um longo suspiro, continuou:

- Houve um dia, um único dia, em que tentei questionar papai sobre como fazer a transição daquilo tudo que estava sendo forçada a mastigar, sobre como apresentar todo aquele discurso a mentes ávidas do amanhã. Ele simplesmente respondeu: Isso não será 
utilizado para nada além daqui, somente precisará disso para conseguir seu posto de operadora. A partir daí, somente as relações que estabeleceu serão importantes. Como podia aquilo? Quais relações eram aquelas, se era exatamente isso que eu estava questionando? O que me restava, após uma resposta daquelas? Conformar-me. E, daquele dia em diante, tomei aquelas palavras como uma espécie de lema: Preciso memorizar tudo e reproduzir. Se tiver que aprender, será por conta própria, e somente assim. No entanto, em alguns momentos de lucidez frente a toda essa hipnose que passei, dia após dia, a me entregar, tentei aprender. Perguntei para alguns irmãos, e eles disseram que deveria aprender tudo aquilo porque era muito importante, porque tinha alguma coisa lá - coisa que nenhum deles conseguiu elucidar, mas de cuja existência tinham absoluta certeza. Tinha alguma coisa lá...

Comecei a compreender Beth. Um desabafo. Somente isso. Uma forma de exteriorizar o que sentiu junto ao caminho percorrido. Não era algo corriqueiro entre os operadores de tinteiro. Todos, até aquele dia, seguraram dentro de si todas essas emoções sem sentido, que não os levariam a nada - a não ser a alguma dor de cabeça no dia seguinte, diante do esforço reflexivo sem nexo. Uma exteriorização de pensamentos que deveriam ficar trancafiados em seu interior, para seu próprio bem - já que a ação de operar um tinteiro não carecia de nenhum daqueles questionamentos.

Seu sonho de instruir mentes futuras seria levado por água abaixo sendo filha de Collins, disso não restavam dúvidas. E talvez tivesse sido por isso que adentrou meu estabelecimento com tamanha decisão: queria falar diante de meu espelho límpido e cristalino, olhar para seus próprios olhos e encarar sua realidade: deveria aceitar seu destino e parar de querer transferir. Deveria criar e traçar, submetendo-se a minha navalha a cada vez que os pelos começassem a crescer nos poros de sua pele, a cada vez que, carecida de lâminas, minhas mãos pudessem repousar sobre ela e aparar tudo o que fosse contrário a traços suaves. Sempre foi assim, e é assim que deveria continuar sendo!

Após outra longa pausa, eis que suas mãos esboçam movimento. Ela moveu os braços. Meu coração disparou. Eu não respirei, à espera de poder vislumbrar aquele calo recémadquirido.

\section{Silêncio.}

Luvas. Sim, luvas é o que vi recobrir a pele de suas mãos. Com um movimento lento e decidido, vi retirar do interior de uma delas três papeis dobrados. Cuidadosamente, com a ponta dos dedos, desdobrou o primeiro deles, segurando os outros dois em uma das mãos. Colocou sobre o assento da cadeira em sua frente, voltando-o para mim. Após perceber que meu olhar voltou-se para a folha rabiscada, prosseguiu:

- Comecei a arquitetar no ano passado. Era o penúltimo ano de instruções com papai e não poderia terminar sem ter plena certeza do que era, de fato, ser transferidora. Eu 
precisava sentir o ar sendo aspirado e respirado em outros ambientes que não fossem os de nossa própria casa, o da casa de papai. Precisava pisar em outro solo, encarar os olhos de outros que não fossem meus irmãos - de sangue ou postiços. E, de forma clandestina, com a ajuda de uma brecha no sistema, a qual me fez ficar no lugar de uma transferidora faltante, adentrei os muros de uma academia de aspirantes. Foi mágico, foi quase uma cena de filme: meus pés começaram a movimentar-se suavemente, meu corpo estava totalmente leve, flutuando. Não sentia nervosismo, não sentia nada além de uma ânsia por poder estar à frente daqueles pequenos seres e externar tudo o que me consumia, na tentativa de procurar em minhas próprias palavras aquilo que tanto perguntei a papai sem ter resposta alguma: Para quê tudo aquilo?

Meus ouvidos não conseguiam mais escutá-la, não conseguiam mais discernir suas palavras de meros sussurros ecoando nas paredes de meu estabelecimento. Como ela atreveuse a colocar um papel sujo de tinta sobre o couro nobre de minha cadeira? Como pôde fazer aquilo, por vontade própria, em um lugar onde somente minha vontade prevalecia? O sangue fervia em meu interior, ao mesmo tempo em que a curiosidade por algo tão novo me tomava. Permaneci imóvel, por mais que a vontade fosse a de esbofetear o rosto daquela menina insolente. Ela desatou a falar:

- Adentrei a sala onde estavam sentadas as mentes ávidas do futuro. Idades cronológicas aproximadas: doze anos. Seres dotados de visões múltiplas, em que cada um era vários, tendo muito a mostrar, muito a exteriorizar. O que poderia fazer naquele momento? $\mathrm{O}$ que poderia eu, frente à tamanha multiplicidade? Preparei-me tanto para o momento de adentrar, vislumbrei tantas possíveis respostas a minha pergunta, que não pensei no detalhe mais importante: o que fazer ali, de frente a todos? A primeira e única opção foi tomar o livro em minhas mãos e desatar pinceladas no quadro vertical cuidadosamente apoiado em uma das paredes que compunham o espaço romboédrico que nos cercava. Pedi para que reproduzissem, queria ver o traçado daqueles seres, queria comparar com tudo o que já tinha visto nos anos de preparação com papai, queria observar tudo o que eles poderiam oferecerme através de seus traços, daquelas mãos suavemente sobrepostas em suas mesas. Com o quadro cheio dos mais belos traços - fiz questão de ser caprichosa, afinal era o momento mais importante de minha vida - comecei a caminhar pelo cômodo, levando meu olhar para as folhas em que os traçados estavam sendo concebidos. Quanta alegria poder estar no meio daquele cheiro de tinta fresca! Era sedutor, mesmo a tinta sendo de má qualidade. Quanta euforia ao poder fazer com que aqueles seres traçassem da mesma maneira que a mim, quanta vontade de transferir tudo o que dentro de mim estava para aqueles compartimentos à espera de algo a completá-los. Meus pés pararam repentinamente, meus olhos fixos em uma folha de papel logo ali, abaixo das mãos pequeninas, rachadas e opacas de Gabriel. 


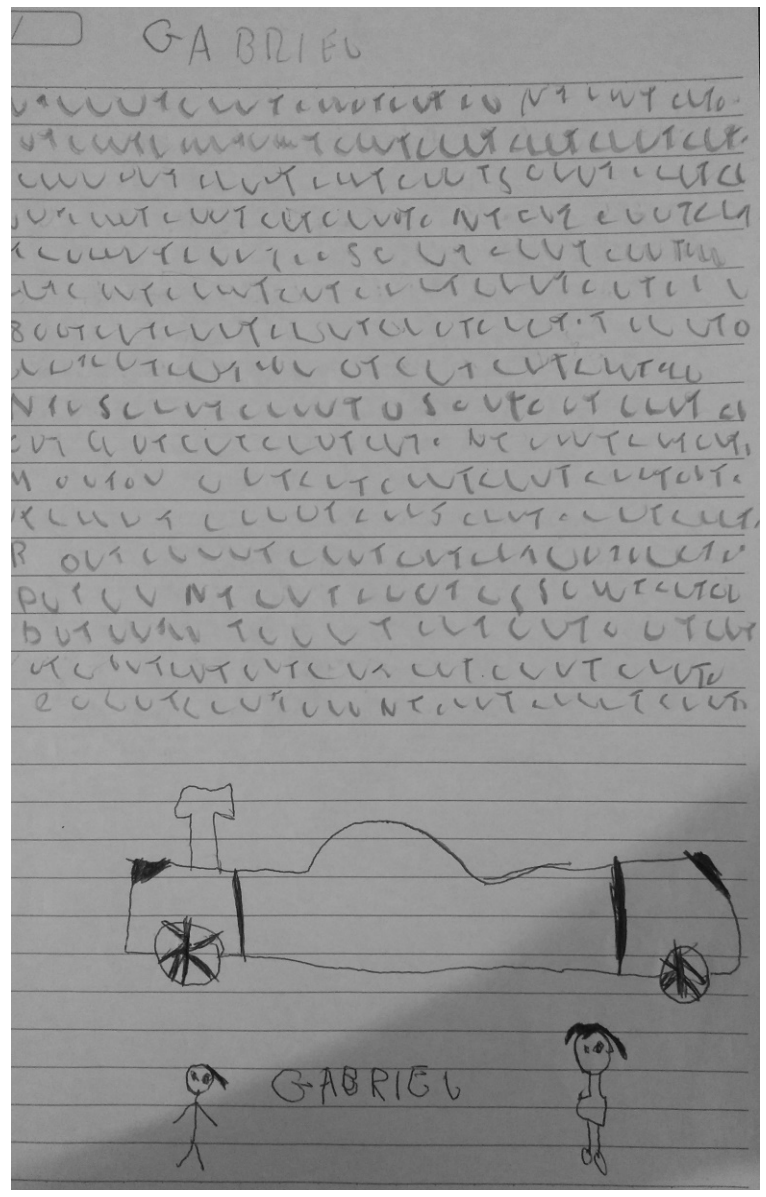

Figura 1 - O traçado de Gabriel Fonte: Acervo pessoal

Confesso que no momento em que Beth pronunciou a palavra mãos, por alguns segundos esqueci por completo sua afronta, me vindo a ocorrer uma imagem de calos instantaneamente. Será que Gabriel tinha calos? Que ideia idiota, é claro que não. Como poderia, ainda mais com um traçado daqueles? Impossível. Nunca os teria. Aliás, a destreza necessária para operar um tinteiro nunca habitaria tal ser. Beth prosseguiu:

— Permaneci cerca de três minutos ao seu lado. Ele não reparou minha presença. $\mathrm{O}$ vazio aniônico que me invadia era tremendo, como uma vastidão sem preenchimento. Seu olhar distante voltado para o quadro, como se conseguisse ver através dele, era constante. Ele praticamente não piscava. Fixava o olhar no quadro e reproduzia em sua folha de papel o que lá estava escrito. A seu modo, por óbvio. Não me contive e perguntei a Gabriel o que estava traçando ali, pedi para que traduzisse alguns daqueles traços para mim, para que eu pudesse averiguar o que estava ocorrendo entre sua mente e o que era representado na folha. Gabriel, ao ouvir minhas palavras, apenas balbuciou algo que não consegui compreender, algo parecido como um não sei gutural. Parecia não fazer ideia do que estava nas páginas, era como se apenas reproduzisse os traços de maneira aleatória, da forma que gostaria que fosse, da forma que os músculos de suas mãos desejavam, e somente aquilo. Todo o resto parecia 
ser composto por detalhes que interessavam somente àqueles preocupados com a forma, com a estética, com as curvas e desníveis de ondulações sobrepostas em terrenos delimitados. Para Gabriel, o que transparecia importar era o preenchimento da folha com seus traços característicos, e mais nada - somente estar ali e permanecer ali, olhando para frente e para baixo, para frente e para baixo, para frente e para baixo, para...

Que sacrilégio, pensei. Como pôde a filha de Collins aceitar aquilo, daquela forma, como se fosse algo corriqueiro? Que formação esse ilustre senhor ofereceu a aquela menina, que se mostrava cada vez mais insolente? Como aceitar um pequeno ser que, ao empunhar um simulador, foi capaz de descrever somente concavidades pontiagudas, assimétricas, despossuídas de leveza e significado? Que foi capaz de traçar uma espécie de veículo, totalmente desforme e irregular? Que concebeu, através dos movimentos de seu próprio punho, dois seres miúdos, despossuídos de narizes, bocas e orelhas, com um deles tendo braços e pernas, mas não possuindo mãos e pés, e o outro tendo somente pernas e pés, sem que braços e mãos fizessem parte de seu corpo? E que penteados eram aqueles? Como aceitar a concepção de corpos sem todos os órgãos? De que me serviriam tais seres manetas? Onde habitariam os preciosos calos?

E, mais que isso: onde se encontrava aquela menina curiosa, dócil e obediente, com o olhar compenetrado nos livros de iniciação? Que moça era aquela que habitava minha barbearia, a qual ousou deflagrar partículas de celulose contra as fibras de couro legítimo que revestiam as almofadas de minha cadeira tão disputada? Tenho certeza de que, se Collins soubesse no que aquela menina havia se metido, iria pessoalmente a aquela academia garantir que tal garoto fosse expulso e nunca mais tocasse em algo parecido com um tinteiro.

Em meio aos meus pensamentos, ouvi os ecos tornando-se cada vez mais altos em minha mente e a voz de Beth passou a atingir meus tímpanos de maneira compreensível novamente:

- Precisava prosseguir, precisava verificar o que aquele ser poderia me oferecer. A curiosidade me dominava e já não pensava mais nos outros pequeninos que lá estavam. Gabriel tomou conta de mim. Apaguei meus belos traços do quadro e, com novas pinceladas, apresentei àquele menino os mais interessantes problemas oriundos dos livros que havia estudado, daquele material tão rico, cujas histórias ensinaram-me que, através daqueles caminhos, seria impossível uma mente não se desenvolver. Os traços básicos, o alicerce de tudo o que fazíamos. Na medida em que ia traçando o quadro, percebia o olhar de Gabriel deslizando para frente e para baixo, naquele movimento repetitivo, como o balançar de um barco, de modo que a cabeça quase recostava a folha de papel no movimento de descida, com a mão direita segurando o simulador grafítico de forma quase boçal, animalesca. Em alguns momentos, ao encará-lo do lugar em que estava, percebia que, às vezes, um pouco de saliva 
escorria pelo canto de sua boca e tocava a folha de papel - imaginei que, se papai estivesse ali naquele momento, daria um tapa tão forte na boca daquele garoto que o deixaria com dor no pescoço no momento em que fosse ter que lamber a folha para recolher a saliva. Mas ele não estava ali, quem estava era eu - seja lá quem fosse eu naquele momento. Gabriel também estava, por completo, totalmente entregue ao movimento de subida e descida. Ao término de meu traçado no quadro, iniciei nova caminhada por entre as mesas - precisava fazer daquela forma para que Gabriel não se sentisse intimidado e freasse o movimento de seu corpo. Ao chegar novamente à mesa daquele menino, deparei com essa folha que agora também será de conhecimento do senhor. Veja, veja com seus próprios olhos o que aquele ser conseguiu produzir junto a meus traçados tão bem feitos, tão bem delimitados. Olhe o que pôde fazer com os problemas que me serviram de base, olhe como ele os resolveu de forma sublime, senhor. Olhe!

E, com um movimento mais ofensivo que aquele que desferiu a primeira folha sobre minha cadeira, desdobrou a segunda, jogando-a por sobre a anterior:

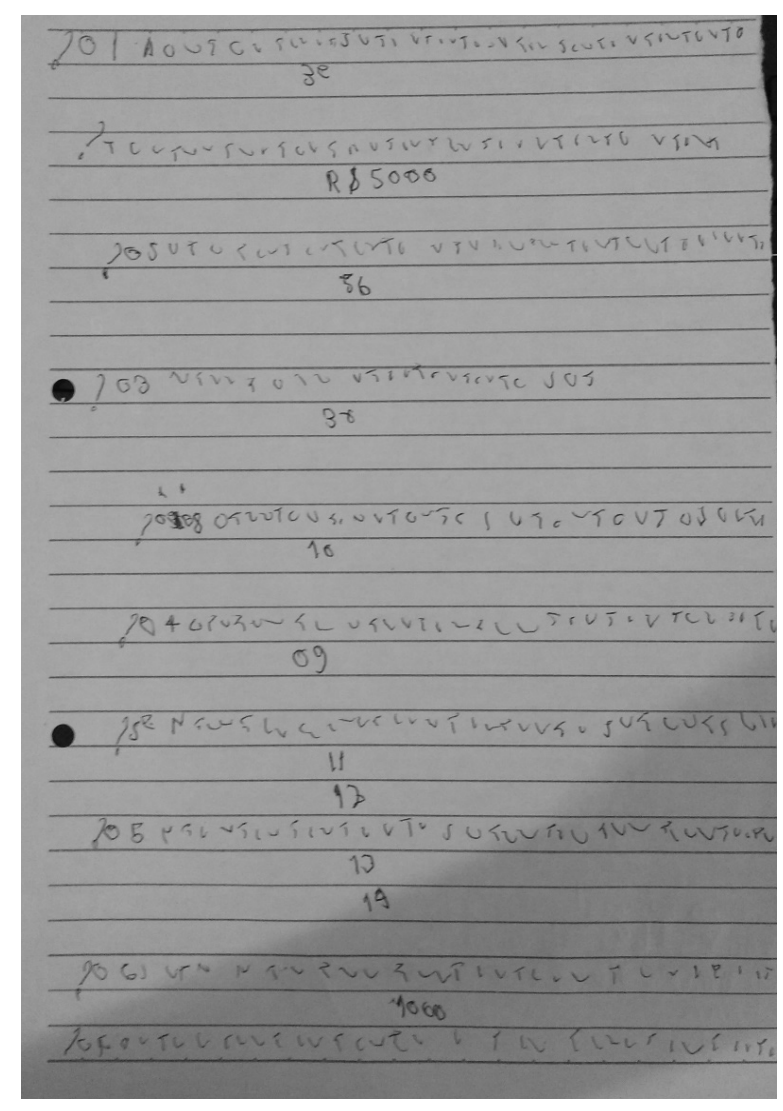

Figura 2 - A resolução de Gabriel Fonte: Acervo pessoal

Eu não podia acreditar em tudo aquilo. $\mathrm{O}$ que aquela menina estava querendo me fazer ver? Traços sem sentido, oriundos de mãos destreinadas e de uma mente certamente perturbada? Era claro que o destino daquele menino não era o de ser aspirante e, se me coubesse decidir seu futuro, obviamente mandaria que o escorraçassem da academia. Veja 
como ele traçou os símbolos sagrados, veja! Não há cadência em suas respostas, não é possível sequer distinguir pelo de pele. Uma mistura, com todos os elementos aglutinados em uma fusão difusa, em que a dispersão era a regra, em que as linhas nada queriam dizer além de coisa alguma, em que os traços - se é que posso chamar assim - destraçavam.

Escorraçá-lo, essa seria a solução. Era a única forma de preservar o alto grau de nossos aspirantes, para que os seres que viessem a ocupar lugar em minha cadeira pudessem trazer calos cada vez mais sublimes. Afinal, não era esse o maior objetivo?

\section{Silêncio.}

Sabe o que mais queria naquele momento em que Beth deflagrou a segunda folha? Agarrá-la, puxar suas luvas e verificar seus calos. Meu corpo estava tremendo, cada partícula de meu ser estava a fervilhar. Sentia toda a barbearia tremer comigo, cada centímetro cúbico de meu ambiente-ser de trabalhado vibrava. Para quê ela estava ali, mostrando-me tudo aquilo? Eu sabia que havia passado pelo rito, sua vestimenta denunciava. Porque as luvas? Por quê?! Bastava me mostrar, sentar-se em minha cadeira e deixar que eu fizesse o resto: empunhar minha navalha e deslizar suavemente por toda a extensão de sua pele, sentir os pelos ouriçarem, como se estivessem suplicando para deitar sobre o fio quente e pulsante de minha lâmina.

A propósito, fazia tempo que meus olhos haviam captado os pelos arrepiados de sua face, principalmente os das orelhas. Ela estava nitidamente alterada e foi somente por isso que permaneci ali, imóvel, recostado em meu balcão. Precisava compreender, necessitava enxergar até onde tudo aquilo chegaria. Precisava continuar escutando aquela voz, por mais que estivesse tornando-se cada vez mais irritante - muito mais irritante do que nas vezes em que, mesmo sabendo que não obteria resposta, perguntava-me acerca de como minha lâmina funcionava. Ela prosseguiu:

- O que mais me deixou encantada com a solução de Gabriel não foram os traços disformes e difusos, os símbolos sagrados utilizados de forma equivocada ou mesmo o símbolo interrogativo aparecendo no início do traçado. Todos estes detalhes eram infinitamente pequenos frente a minha total admiração ao deparar com algo nunca antes visto em minha existência, jamais contemplado em nenhum dos livros traçados pelos grão-mestres. Em nenhuma das páginas que passaram pela frente de minhas retinas pude captar algo parecido com aquilo que Gabriel produzira, em nenhuma conversa com os irmãos, postiços ou não, escutei algum relato parecido. Nem mesmo papai, tão influente e com vivências tão amplas quanto sua fama, citou, mesmo que nas entrelinhas, alguma anedota que chegasse perto daquele fato inexorável vivenciado por mim, ali, naquele momento. Eu estava paralisada, ao vislumbrar tamanha beleza criativa. Tentava classificar a obra de Gabriel, mas, 
por mais que percorresse meus mapas mentais, não conseguia encontrar categoria que elencasse aquelas linhas.

Escutava tudo aquilo como se estivesse tomando o relato de uma pessoa atormentada, fora de si. Será que aquela menina havia feito uso de substâncias tóxicas e aquilo tudo não passava de um delírio?

- Na tentativa de compreender alguma coisa, pois já não me sentia apta a transferir algo para aquele pequeno, fui, mais uma vez, em direção ao quadro e apaguei os traços anteriores, tão bem delineados, totalmente fieis às referências que trazia de cor. Voltei-me a Gabriel, andando em direção a ele, somente a ele. Agachei-me ao seu lado, mostrei o simulador e disse: Trace o que vê. Não sabia o que aconteceria após aquele comando, nunca havia pensado na possibilidade de traçar algo que estivesse fora do escopo do que já foi traçado, do que já foi delineado, do que já foi mapeado. Como disse, foi uma espécie de visão, algo que me atingiu vindo de fora. As palavras vieram a minha boca, e eu as pronunciei, quase junto aos ouvidos de Gabriel, que parece ter recebido aquilo como um sopro de vida. Ele começou a traçar, sorrindo de canto de boca, alguma baba ainda caía em sua mesa, mas ele não ligava. Naquele momento, nem eu me importava. Fiquei ali, ao seu lado, agachada, observando suas mãos bailando sobre a folha, tentando decifrar quais técnicas estavam sendo utilizados para traçar linhas tão belas, tão cheias de algo que nunca havia visto até então. Por mais que tentasse, não conseguia entender. Ele passeava pela folha. Já não sabia mais distinguir Gabriel de sua mão, e sua mão de seus traços, e seus traços de nosso entorno. Eu vi.

E desdobrando a última folha, com as mãos trêmulas, os olhos marejados, as mandíbulas rangendo, desferiu o último golpe em minha cadeira:

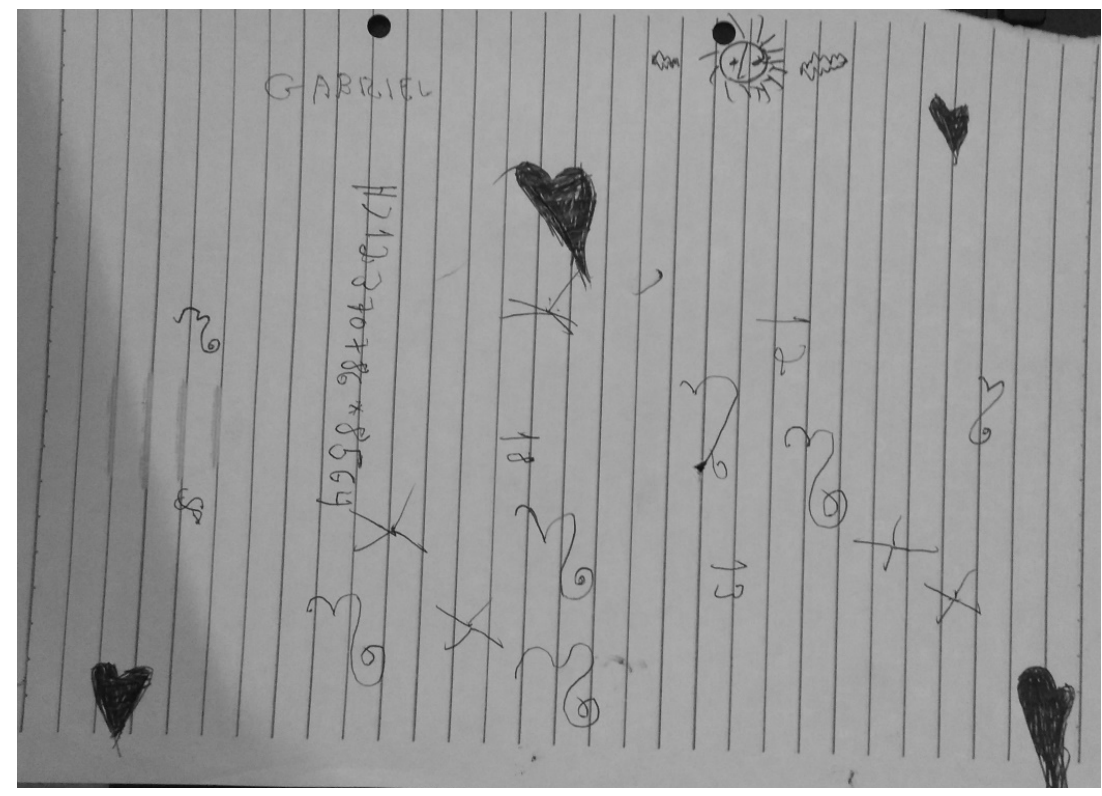

Figura 3: A visão de Gabriel

Fonte: Acervo pessoal 
Depois de todo aquele discurso, daquele suspense quase teatral protagonizado por Beth, tendo como coadjuvante minha própria poltrona, o mínimo que queria ter frente às minhas retinas era uma obra de arte, algo que me fizesse ficar por alguns segundos parado, buscando a compreensão, decifrando os encadeamentos lógicos de certa cadência um pouco mais complexa do que a comum. Algo com poucos pelos ou, ao menos, com um comprimento aceitável. Mas ao olhar para aquela bola peluda, terceiro momento visual de seu discurso, o que vejo? Símbolos sagrados conduzidos de forma aleatória, corações preenchidos de forma compulsória, algumas linhas cruzadas e várias curvas assimétricas, totalmente perdidas num espaço vazio sob a face do astro rei!

Ela acabara de me dizer que tinha visto. Tinha visto o quê? Ela estava em uma dimensão paralela para que o entorno fosse concebido de forma tão disforme? Que diabos essa menina pretendia ao regurgitar aquelas visões infernais, sandices oriundas do encontro com um ser esquizofrênico e infame?

- Gabriel parecia flutuar - era como se eu pudesse sentir seus pezinhos balançando debaixo da mesa. Seu trabalho havia terminado, ele estendeu a mão e entregou-me também aquela folha. Meus olhos não conseguiam ver outra coisa que não fossem seus traços, totalmente precisos, harmoniosos, trazendo-me algo totalmente novo, uma beleza desconhecida. Tomei a folha de sua mão, dei um sorriso, levantei-me e fui guardar aquela preciosidade junto às outras, dentro de minha bolsa. Eu teria que analisar com calma tudo aquilo, verificar nos catálogos mais antigos o que poderia significar a intensidade da obra de Gabriel.

\section{Silêncio.}

- Risadas. Escutei risadas, muitas. Olhei para trás e percebi que todos os dedos indicadores dos pequenos apontavam para Gabriel, que com a cabeça baixa, encarava o chão, imóvel, sem reação alguma. Aquele sorriso de segundos atrás havia desaparecido de seus lábios, restando somente a saliva que desatava a escorrer. O cheiro. Forte. Urina. Deve ter sido a felicidade tremenda, deve ter sido a forma que Gabriel encontrou de me mostrar que estava explodindo por dentro, desaguando seu próprio ser para que suas águas encontrassem as minhas. Ou então, numa visão menos egoísta, poderia ter sido o alívio por ter terminado mais uma daquelas atividades que o deixava sob pressão, num estado de constante tensão e desconforto. Quem sabe? Só sei que via aquele líquido amarelado escorrendo por suas pernas, manchando a calça jeans surrada e empoçando logo abaixo de seus pés descalços. Fiquei imóvel, não sabia o que fazer, não sabia como proceder para que aqueles pequenos parassem de apontar para aquele ser, para que parassem de rir. Devido ao barulho, percebi que alguém surgiu à porta. Só tive tempo de sentir uma mão agarrando-me pelos braços, tirando-me violentamente daquele espaço romboédrico. Minhas únicas reações foram as de empunhar 
minha bolsa com as preciosidades de Gabriel e de dar uma última olhada para aqueles olhos que habitavam novamente o vazio. Jogaram-me contra o chão e disseram-me para nunca mais voltar. Não havia como respeitar aquele comando, visto que meu ser passou a habitar as mãos trincadas de Gabriel. Já não era mais eu. Já não era mais. Já não era. Já não. Já...

Era o limite. Tudo aquilo para concluir que o infame era mijão? Todo esse ensaio para me mostrar que há alguém que produziu rabiscos sem sentido, para me revelar o quanto ficou tocada com tudo aquilo? Toda essa odisseia para ficar impregnada de amônia? Esbocei um pequeno movimento no intuito de retirar aquelas folhas de cima de minha cadeira, imaginando-me de posse de um pano com álcool para esterilizá-la. Beth percebeu minha intenção e, como um gato treinado, pulou sobre minha cadeira. Ficou ali, amassando as folhas com seus pés que, naquele momento, percebi estarem descalços. Pés lisos, com as unhas feitas, pisando as folhas, deixando o couro todo amassado.

Antes de eu poder levar minhas mãos ao encontro de seu pescoço para enforcá-la pois era isso o que mais queria fazer naquele momento - Beth deu início ao movimento, o qual teve o poder de me deixar estático novamente, de me seduzir: vagarosamente, olhando para as próprias mãos, começou a despir a luva da canhota. Puxou inicialmente o dedo indicador, seguido pelo mindinho, passando pelo anelar e finalizando com o médio. A luva foi jogada ao chão. Tire a outra, menina. Tire! E, com a mesma paciência e suavidade, repetiu o gesto com a luva da mão direita. Jogou-as também ao chão. Meus olhos não se importavam com aquele pano contaminando o piso de minha barbearia, o que queria eram seus calos, que agora seriam totalmente meus, meus!

Luvas vermelhas? Não era possível que estivesse utilizando dois pares de luvas. O que significava aquilo? Que cheiro era aquele? Seria a amônia ainda impregnada em sua pele? Não... Conhecia aquele cheiro da época do treinamento com couro suíno. Conhecia muito bem aquele aroma de ferrugem. Sangue. Nunca em minha barbearia uma gota sequer foi extraída, nunca poderia manejar a navalha se assim o fosse.

— Não foi fácil conseguir distrair o senhor, caro barbeiro. Foram semanas a fio, demonstrando todas as minhas habilidades perante papai e o senhor. Inicialmente, gostava daquilo, de me sentir vangloriada, de sentir que estava sendo observada por alguém tão influente e importante, por alguém que tocava e modificava tudo e todos nesta ilustre cidade. Queria aquilo, e a cada vez que vinha acompanhada de papai, me esforçava ao máximo para chamar a sua atenção. Mas não os tinha, não é mesmo? Ainda não tinha aquilo que seus olhos procuravam a cada vez que me via. Mesmo aparando meus cabelos com sua tesoura obsoleta, mesmo naqueles momentos sentia seu olhar abaixando e procurando em minhas falanges o seu tesouro. Como quis dar-te aquilo. Como quis poder chamar a atenção do senhor como papai fazia. Conseguir ver seus olhos brilhando da mesma forma quando encarava a destra de 
papai. Durante muito tempo esse foi meu sonho, mas meus irmãos mostraram-me o caminho paralelo do qual falei. Levaram-me a questionar o que estava lá e, de alguma forma impensável, presentearam-me com a possibilidade de estar com aquele ser.

Silêncio.

- $\mathrm{O}$ encontro com Gabriel trouxe-me o elemento que faltava, levou-me para fora de tudo o que conhecia e trouxe-me novamente, acompanhada de uma ranhura em minha pele, uma fresta, uma ruptura. Um buraco por onde poderia empreender fuga sempre que desejasse pensar em possibilidades outras... O final dos encontros de instrução junto a papai estava se aproximando e, a cada nova fuga por meio das linhas de Gabriel, novas frestas e ranhuras passavam a me habitar. A cada noite sem dormir, o pensamento era um só: preparar um discurso para apresentar no dia da iniciação, mostrando essa nova possibilidade de traços, essa nova maneira de empreender linhas sobre a folha inerte, de empreender velocidade a algo que sempre foi desacelerado. Em um dos infindáveis jantares em nossa casa decidi comentar com papai sobre a possibilidade de um discurso outro, de uma nova construção discursiva perante a ilustre banca examinadora. Sua resposta foi incisiva: Não fale bobagens, faça o que tem que ser feito e pronto. Fiquei atônita. Fiquei com raiva. Fiquei enfurecida.

Ali, de frente para aquele ser, pude ver seus olhos avermelhando-se, as lágrimas, enfim, rolando pela sua face e misturando-se à tinta das folhas sob seus pés, manchando-as e também ao couro - que já não estava mais lustrado ou liso.

— Por que ele era daquele jeito? Porque não se permitir olhar de outra forma, porque uma pele tão lisa e livre de qualquer pelo que fosse? Olhei para os rostos de meus irmãos, os mais velhos que seguiram os passos de papai, e via que todos, sem exceção, tinha-os aparados, lisos. Porque haveria de ser daquela forma e nunca de outra?!

Sempre foi assim minha cara, não faça perguntas idiotas!

- Depois daquele dia, só havia uma maneira de chamar a atenção. Só havia uma forma de mostrar o que estava querendo dizer. Somente um ato poderia modificar aquela situação e fazer com que as ranhuras da pele de Gabriel saltassem de minha cútis e pudessem, mesmo que por alguns segundos, habitar outro lugar que não fosse o nós.

Silêncio.

- Sempre via aquela gaveta vermelha, ali no canto, isolada de tudo. Sempre me questionei sobre o que havia dentro dela, sempre. Perguntei várias vezes ao senhor o que havia dentro, mas nunca obtive resposta. Aliás, o senhor nunca responde, nunca escuta. Cansei-me de perguntar como sua navalha funcionava. Já me acostumei aos seus ouvidos de desdém.

Olhar de desdém. 
- Ao final do trabalho com papai, com cerca de trinta e seis minutos, o senhor sempre olhava para seus calos de forma hipnótica, um verdadeiro transe. Percebi isso. Ir até a gaveta e, após, olhar o que tinha dentro, foi somente uma questão de coragem. Abri. Olhei. Navalhas antigas. Muitas. Tomei uma, não resisti. A curiosidade pelo seu funcionamento me tomou. Não sabia o que fazer com ela. Não sabia se o senhor sentiria falta dela ou não. Não sabia nem se deveria saber de algo. Apenas fiz.

Saí correndo rumo a minha gaveta. Como pôde?! Ousar tocar em uma vida toda de trabalho e dedicação? Onde estava?

- É isso o que procura, caro senhor? É bonita. Meio cega, mas foi útil para o que precisei fazer.

Olhei por cima dos ombros, ela estava com uma das mãos ensanguentadas erguida, encarando-me pelo reflexo no espelho. Já eu, ajoelhado de frente a minha gaveta de navalhas defeituosas. Instrumentos podem ficar obsoletos, e devem ser trocados de tempos em tempos. Ela estava com a de cabo de madeira. Foi muito útil durante um bom tempo, mas o estilo moderno me fez ter que substituí-la. Deixei-a ali, guardada junto às outras, como sempre fazia, por uma questão de gosto. E gosto, não se discute.

Como poderia imaginar que uma menina pegaria uma de minhas lâminas aposentadas? Ninguém nunca fez aquilo, nunca. Sempre se preocupavam somente com a navalha que estava a alisar sua pele, e somente com aquela. As outras sempre caíam no esquecimento e no desuso. Era assim, sempre foi assim.

\section{Diabos!}

Estava ainda ajoelhado, quando percebi que aquela desequilibrada, suavemente, começou a descer da cadeira e, vagarosamente, locomoveu-se em minha direção. A navalha em uma das mãos, e a outra, punho cerrado. Ousaria me bater? Tentaria me atingir? Ao chegar perto, estendeu a mão cerrada, com os dedos voltados para baixo e ficou ali, parada, encarando-me nos olhos e esperando alguma reação de minha parte. Levantei-me e a encarei também, friamente. Menina insolente! Ela esperava algo. Estiquei minha mão. Compreendi que queria dar-me alguma coisa.

— Tome, senhor. Era isso que sempre quis.

E, num gesto suave, abriu o punho cerrado e dele caíram duas corcovas. Reconheci de imediato, sabia de cada poro, de cada ondulação daquele calo magnífico. Fiquei encarando aquela coisa bela, extraída com tamanha precisão. Imaginei-o de imediato pregado em minha parede, ao lado da foto daquele que era um dos mais ilustres frequentadores de meu estabelecimento. $O$ que essa menina acabou de fazer foi maravilhoso! Sempre quis aqueles calos em minhas mãos, e naquele momento se tornaram meus, somente meus e de mais ninguém. A vontade era a de beijar as doces mãos daquela menina. Tudo estava explicado, 
todo aquele delírio foi o modo que escolheu para demonstrar, utilizando o absurdo, que seus passos estavam totalmente alinhados. Naquele momento, queria seus calos mais do que nunca.

Para mim, a explicação era muito simples: entorpeceu o pai no almoço de comemoração ao rito de iniciação e, com minha navalha obsoleta, mas ainda afiada, extraiu aquele tesouro, vindo entregar-me pessoalmente. Com aquilo, demonstraria sua maioridade, demonstraria que estaria ali sempre que desejasse aparar os fios de pelo que nascessem por sobre sua pele. Ela foi por si própria, ofertar-me aquele sacrifício como uma forma de dizer: sou tua agora, apara-me.

Em meio àquela doce conclusão, ainda com os olhos fixos sobre meu tesouro, repentinamente senti o vestido de Beth mover o ar a nossa volta. De súbito, saiu correndo em direção ao balcão, debruçando-se sobre ele. Não saí do lugar, estava onde queria estar e com aquilo que tanto desejava sob minha posse. Somente desviei o olhar levemente para sua direção, para averiguar o que faria. Já não esperava mais nada daquele ser que teve a capacidade de agraciar-me com tamanho presente, chegando ao ápice: dilacerar a mão paterna para satisfazer uma vontade minha, vontade essa captada por seus próprios olhos, por seu próprio pensamento. Certamente, limparia suas mãos para que me fosse possível vislumbrar seu calo e, logo em seguida, sentaria em minha cadeira - ainda suja de tinta e lágrimas, mas não importaria. Não naquele momento, em que teria em minha frente, sob o fio de minha navalha, aquela pele fresca e cheia de pelos para aparar.

No entanto, debruçada por sobre o balcão, Beth encarou-me através do espelho e falou:

- Sei muito bem que sempre quis meus calos. Por muitas vezes observei o senhor olhando para minhas mãos, verificando se já estavam lá. Não foram poucas as vezes que trouxe livros para cá, somente para escondê-las sob suas páginas. Ficava lendo e relendo as mesmas passagens e, após o encontro com Gabriel, o que estava dentro dos livros era sua obra. Eram meus traços acerca dos traçados dele, minhas reflexões acerca de suas curvas, de seu modo de ver e interpretar o que nos cerca. A cada semana, aqui nesta barbearia, assim como na casa de papai, as linhas de Gabriel foram minha fuga, refúgio de seu olhar, do desejo de papai por me tornar uma operadora de tinteiro, de seu desejo por meus calos e, consequentemente, por minha pele virgem e cheia de pelos. Por cima das páginas, observava cada movimento, cada sorriso de canto de boca enquanto passava sua lâmina na pele de papai, enquanto aparava todos os pelos de sua face, de sua cabeça, de seu corpo, deixando-o totalmente liso para que, na próxima semana voltasse e iniciasse o mesmo ritual. Comecei a sentir nojo dessa lâmina. Comecei a sentir uma verdadeira repulsa e, assim como Gabriel, comecei a apenas olhar para frente, e para baixo, para frente e para baixo, num movimento 
constante, com métrica exata para satisfazer papai, e você, certamente. O dia da iniciação estava chegando. Papai foi dormir muito orgulhoso de mim, afinal hoje seria a iniciação, o dia em que sua filha tomaria posse da tão esperada habilitação, o tão sonhado cilindro, feito de suor e muito, muito sangue - sangramos muito antes de começarmos a frequentar sua barbearia, sabia? Às vezes tentamos arrancar os pelos com as unhas e sempre nos machucamos. Papai repudiava este ato, fazia isso mais quando era menor.

Por isso alguns tinham, em algumas pequenas partes, poros mais protuberantes que o normal...

- Hoje pela manhã, ao acordar, a primeira coisa que fez foi bater na porta de meu quarto e lembrar-me do grande dia. Havia passado a noite toda em claro, agarrada ao trabalho de Gabriel e a sua navalha. Só conseguia pensar no mar que desaguou daquele ser. Só conseguia imaginar como seria navegar no encontro de suas águas com as minhas, em um fluxo de água totalmente sem margens, em que seria empurrada somente pela força do meio... Comecei a me vestir, a colocar o vestido, a enrolar a fita azul na cintura. Sabia que papai faria questão de fazer meu coque, ele sempre deixou isso bem claro. Seria aquele o momento. Sentada, de frente ao espelho de minha cômoda, a navalha por debaixo da saia do vestido. As mãos dele sendo observadas atentamente através do reflexo. $\mathrm{O}$ arremate final em meu coque, o último movimento. Um corte. Um grito. Sangue. Corri. E cá estou.

As palavras daquela menina atingiram-me como o fio de minhas navalhas. Tudo aquilo era surreal: o presente que acabara de receber era um símbolo de asco completo por tudo o que fazia, por todo o meu esforço para manter esses habitantes, incapazes de se depilarem, livres de seus pelos perturbadores. E, sem que pudesse terminar de concluir tal pensamento, Beth empunhou, com a canhota, a navalha de cabo de madeira, ergueu-a por sobre a altura de seus ombros, desferindo o golpe fatal em suas falanges.

Silêncio.

Lembro-me do sangue. O sangue doce e vermelho a escorrer através de meu balcão, descendo até encontrar o chão - o qual estava impecavelmente limpo à espera de Collins. E ali, por sobre a tábua, seus dedos permaneceram inertes. Ela correu. Nunca mais a vi.

\section{'Silêncio.}

'Caminhei lentamente em direção ao balcão. As luvas ao chão, as folhas ainda sobre minha cadeira, os dedos apoiados sobre a mesa. Agarrei o médio com todo o amor e carinho que sentia por aquela que foi por tanto tempo objeto de meu desejo. Lambi com toda a ternura e deslumbramento que tenho por mãos, ainda mais por aquelas. Lambi para sentir o gosto do sangue e para retirá-lo do caminho. Precisava repousar meus olhos sobre aquele calo, precisava sentir sua textura, precisava averiguar seus menores detalhes - mesmo que estivesse 
encrustado em um dedo sem vida. Mas o calo não estava lá. Verifiquei em todos os outros, lambi todos. Nada. Não havia calos.

Foi difícil limpar toda aquela sujeira. As luvas de Beth estavam com sangue e sujaram o chão. O mesmo ocorreu com o balcão, que precisou ser pintado novamente, após severas horas de limpeza. As folhas produzidas pelo menino desequilibrado serviram muito bem para embrulhar os dedos de forma a serem levados ao lixo sem que ficassem soltos. Passei horas lustrando o couro de minha cadeira, e ouso dizer que ficou muito mais vigorosa do que antes. Terminei e olhei ao redor, atentando ao pequeno cadeado na gaveta vermelha. Balancei a cabeça afirmativamente, estava feito. Minhas pernas doíam. Sempre doíam, mas, naquele dia, depois do fato ocorrido, senti que a dor era muito mais forte. Precisava repousar, mesmo que fosse somente por alguns segundos. Tentei lembrar-me do momento em que havia repousado desde que abri a barbearia. Não consegui. Talvez fossem as cortinas do tempo que me impediam de ver. Não importava. Iria me sentar, rapidamente, e esticar minhas pernas sobre o balcão. Seria rápido. Sentei em minha cadeira. Como era macia... Como era aconchegante... Levantei a perna direita, repousei sobre o balcão e suavemente, repousei a perna esquerda por sobre a direita. Olhei para cima e fechei os olhos, respirei fundo, os braços apoiados nos apoios da cadeira, também acolchoados. Olhei para frente, para o espelho. Meus pés estavam descalços. Eu tinha pelos nas solas dos pés.

\section{Referências}

DELEUZE, G. GUATTARI, F. O que é Filosofia? São Paulo: Editora 34, 2010.

DELEUZE, G. GUATTARI, F. Mil Platôs: capitalismo e esquizofrenia 2. vol. 1. São Paulo: Editora 34, 2011.

FOUCAULT, M. A Arqueologia do Saber. Rio de Janeiro: Editora Forense-Universitária, 1987.

FOUCAUlT, M. As Palavras e as Coisas. São Paulo: Livraria Martins Fontes Editora Ltda., 1992a.

FOUCAULT, M. O que é um autor? Lisboa: Passagens, 1992b.

FOUCAULT, M. A Ordem do Discurso. São Paulo: Edições Loyola, 2000.

GOMES, D. O. A Disciplina de Análise segundo Licenciandos e Professores de Matemática da Educação Básica. Dissertação de Mestrado em Educação Matemática - Universidade Estadual Paulista Júlio de Mesquita Filho, Rio Claro, 2013.

GOMES, D. O.; OTERO-GARCIA, S. C.; SILVA, L. D.; BARONI, R. L. S. Quatro ou Mais Pontos de Vista sobre o Ensino de Análise Matemática. BOLEMA: Boletim de Educação Matemática. v.29, n. 53, p. 1242-1267, 2015. 
GONDIM, D. M.; GOMES, D. O. Entre Definições, Teoremas e Demonstrações: discursos de rigor ou rigor(es) discursivo(s)? In: XII ENCONTRO NACIONAL DE EDUCAÇÃO

MATEMÁTICA. 2016, São Paulo. Anais do XII Encontro Nacional de Educação Matemática - ENEM. São Paulo, 2016.

LISPECTOR, C. Água viva. Rio de Janeiro: Nova Fronteira, 1987.

NIETZSCHE, F. W. O crepúsculo dos ídolos: ou a filosofia a golpes de martelo. São Paulo: Hemus, 1976.

NIETZSCHE, F. W. Assim falava Zaratustra. São Paulo: Companhia das Letras, 1998.

ZUSAK, M. A Menina que Roubava Livros. Rio de Janeiro: Intrínseca, 2007.

\section{SOBRE O AUTOR}

DANILO OLIMPIO GOMES. Licenciado em Matemática pelo Centro Universitário UniFafibe - Campus Bebedouro/SP (2008), mestre em Educação Matemática pela Universidade Estadual Paulista Júlio de Mesquita Filho, UNESP - Campus Rio Claro/SP (2013) e doutorando em Educação Matemática pela Universidade Estadual Paulista Júlio de Mesquita Filho, UNESP - Campus Rio Claro/SP (início em 2016). Atualmente é professor do Ensino Básico, Técnico e Tecnológico no Instituto Federal de Educação, Ciência e Tecnologia de Alagoas - IFAL, Campus Piranhas; Membro do grupo de estudo/orientação CRONÓPI@S, onde discussões acerca de obras afins da Filosofia, Filosofia da Educação Matemática, Filosofias da Diferença, Etnomatemática e História da Matemática ocorrem de forma periódica junto aos departamentos de Educação/Educação Matemática da UNESP de Rio Claro/SP; Participação no grupo de pesquisa I-mago (Laboratório de Experiência e Cria[@]cão), UNESP - Rio Claro/SP. 